\title{
SISTEM PENUNJANG KEPUTUSAN UNTUK PENANGANAN PENDERITA GAGAL JANTUNG
}

\author{
Eddy Sutedjo $^{1}$; Dedi Trisnawarman ${ }^{2}$; Ferdinand Hartanto ${ }^{3}$ \\ ${ }^{1}$ Jurusan Komputerisasi Akuntansi, Fakultas Ilmu Komputer, Bina Nusantara University \\ Jln. KH Syahdan No 9, Palmerah, Jakarta Barat 11480 \\ ${ }^{2}$ Fakultas Teknologi Informasi, Universitas Tarumanagara \\ ${ }^{3}$ Jurusan Sistem Informasi, Fakultas Teknologi Informasi, Universitas Tarumanagara \\ Jln. Letjen S. Parman No 1, Grogol, Jakarta Barat 11440
}

\begin{abstract}
Technology is one important factor that supports accuracy result of a disease in health. Along with technology, one's knowledge could be broadening so he can make one exact decision about specific disease to get maximal result. Based on above considerations, it is designed a supporting decision-making system based on entered data, processed using weighting in AHP to know the result. The programming language is using PHP and the database using MySQL. The designing result could help doctors to choose specific medicine for the patients and help them to find information about cardiac failure and what stages to be done to help the patients healing.
\end{abstract}

Keywords: AHP, decision support system, health, cardiac failure

\begin{abstract}
ABSTRAK
Teknologi merupakan salah satu faktor penting yang dapat mendukung keakuratan hasil suatu penyakit dalam bidang kesehatan. Dengan adanya teknologi, pengetahuan seseorang dapat menjadi lebih luas sehingga dapat mengambil suatu keputusan yang tepat akan penyakit tertentu untuk mendapatkan hasil yang maksimal. Berdasarkan pertimbangan-pertimbangan di atas, maka dirancanglah suatu sistem penunjang keputusan untuk penanganan penderita gagal jantung. Pengambilan keputusan sistem ini dilakukan berdasarkan data yang dimasukkan, diolah dengan mengunakan metode pembobotan AHP untuk kemudian keluar hasil akhirnya. Adapun bahasa pemrograman yang digunakan adalah PHP dan MySQL sebagai basis datanya. Hasil rancangan dapat membantu dokter dalam memilih obat yang sesuai bagi penderitanya dan membantu penderita dalam mencari informasi seputar gagal jantung serta langkah apa saja yang harus dilakukan penderita untuk cepat sembuh.
\end{abstract}

Kata kunci: AHP, decision support system, kesehatan, gagal jantung 


\section{PENDAHULUAN}

Fungsi dasar komputer saat ini adalah menerima masukan berupa data. lalu diolah menjadi keluaran yang disebut dengan informasi. Informasi inilah yang dapat membantu seseorang untuk memutuskan sesuatu hal dengan membacanya. Salah satu bidang ilmu yang mengaplikasikannya adalah Decision Support System atau Sistem Penunjang Keputusan. Pengambilan keputusan sistem ini dilakukan berdasarkan data yang dimasukkan, diolah untuk kemudian keluar hasil akhirnya.

Berdasarkan pertimbangan-pertimbangan di atas, maka dirancanglah suatu sistem penunjang keputusan untuk penanganan penderita gagal jantung. Perancangan ini diharapkan dapat membantu dokter dalam memilih obat yang sesuai bagi penderitanya dan membantu penderita dalam mencari informasi seputar gagal jantung serta langkah-langkah apa saja yang harus dilakukan penderita untuk cepat sembuh. Perancangan sistem penunjang keputusan untuk penanganan penderita gagal jantung ini menggunakan aplikasi perangkat lunak XAMPP yang meliputi MySQL sebagai basis data dan server basis data, Apache sebagai web server, bahasa pemrograman PHP, dan Adobe Dreamweaver CS4 serta Adobe Flash CS3 untuk rancangan antarmukanya.

\section{Landasan Teoritik}

Sistem yang dirancang adalah sistem penunjang keputusan yang dapat digunakan untuk manangani penderita gagal jantung. Sistem ini membantu dokter untuk memilih obat yang tepat berdasarkan kontraindikasi yang diderita pasien. Sistem ini dirancang menggunakan Entity Relationship Diagram (ERD) dan hubungan antar tabel, untuk menggambarkan hubungan antar entitas dalam sistem.

\section{Sistem Penunjang Keputusan}

Little dalam Turban, Aronson \& Liang (2005) mendefinisikan DSS sebagai sekumpulan prosedur berbasis model untuk data pemrosesan dan penilaian guna membantu para manajer mengambil keputusan. Sedangkan, menurut McLeod (2001), sistem pendukung keputusan adalah sistem yang mendukung manajemen pendukung manajemen pembuat keputusan dengan mengkombinasikan peralatan dan model data analisis, dan perangkat lunak yang user-friendly ke dalam sebuah sistem tunggal yang kokoh yang bisa mendukung pembuatan keputusan semi terstruktur dan tidak terstruktur.

\section{Komponen-Komponen DSS}

Menuru Turban, Aronson \& Liang (2005), aplikasi DSS dapat terdiri dari subsistem, yaitu subsistem manajemen data, manajemen model, antarmuka pengguna, manajemen berbasis pengetahuan.

\section{Subsistem Manajemen Data}

Subsistem manajemen data memasukkan satu basis data yang berisi data yang relevan untuk situasi dan dikelola oleh perangkat lunak yang disebut sistem manajemen basis data (DBMS). Subsistem manajemen data dapat diinterkoneksikan dengan data warehouse perusahaan, suatu repositori untuk data perusahaan yang relevan untuk pengambilan keputusan. Biasanya data disimpan atau diakses via server web basis data. 


\section{Subsistem Manajemen Model}

Merupakan paket perangkat lunak yang memasukan model keuangan, statistik, ilmu manajemen atau model kuantitatif lainnya yang memberikan kapabilitas analitik dan manajemen perangkat lunak yang tepat. Bahasa-bahasa pemodelan untuk membangun model-model kustom juga dimasukkan. Perangkat lunak ini sering disebut sistem manajemen basis model (MBMS). Komponen ini dapat dikoneksikan ke penyimpanan korporat atau eksternal yang ada pada model. Sistem manajemen dan metode solusi model diimplementasikan pada sistem pengembangan Web (seperti Java) untuk berjalan pada server aplikasi.

\section{Subsistem Antarmuka Pengguna}

Pengguna berkomunikasi dengan dan memerintahkan DSS melalui subsistem ini. Pengguna adalah bagian yang dipertimbangkan dari sistem. Para peneliti menegaskan bahwa beberapa kontribusi unik dari DSS berasal dari interaksi yang intensif antara komputer dan pembuat keputusan. Browser web memberikan struktur antarmuka pengguna grafis yang familier dan konsisten bagi kebanyakan DSS.

\section{Subsistem Manajemen Berbasis Pengetahuan}

Subsistem ini dapat mendukung semua subsistem lain atau bertindak sebagai suatu komponen independen. Memberikan inteligensi untuk memperbesar pengetahuan si pengambil keputusan. Subsistem ini dapat diinterkoneksikan dengan repositori pengetahuan perusahaan (bagian dari sistem manajemen pengetahuan), yang kadang - kadang disebut basis pengetahuan organisasional. Pengetahuan dapat disediakan via server Web. Banyak metode kecerdasan tiruan diimplementasikan dalam sistem pengembangan Web seperti Java, dan mudah untuk diintegrasikan dengan komponen DSS lainnya.

\section{Analytical Hierarchy Process (AHP)}

Dengan menggunakan AHP, suatu persoalan yang akan dipecahkan dalam suatu kerangka berpikir yang terorganisir, sehingga memungkinkan dapat diekspresikan untuk mengambil keputusan yang efektif atas persoalan tersebut. Persoalan yang kompleks dapat disederhanakan dan dipercepat proses pengambilan keputusannya (Marimin, 2004).

Beberapa keuntungan yang diperoleh bila memecahkan persoalan dan mengambil keputusan dengan menggunakan AHP adalah: (1) kesatuan, AHP memberikan satu model tunggal yang mudah dimengerti, luwes untuk aneka ragam persoalan tidak terstruktur; (2) kompleksitas, AHP memadukan ancangan deduktif dan ancangan berdasarkan sistem dalam memecahkan persoalan kompleks; (3) saling ketergantungan, AHP dapat menangani saling ketergantungan elemen-elemen dalam suatu sistem dan tidak memaksakan pemikiran linier; (4) penyusunan hierarki, AHP mencerminkan kecenderungan alami pikiran untuk memilah-milah elemen-elemen suatu sistem dalam berbagai tingkat berlainan dan mengelompokan unsur yang serupa dalam setiap tingkat; (5) pengukuran, AHP memberi suatu skala untuk mengukur hal-hal dan terwujud suatu metode untuk menetapkan prioritas; (6) konsistensi, AHP melacak konsistensi logis dari pertimbangan-pertimbangan yang digunakan untuk menetapkan berbagai prioritas; (7) sintesis, AHP menuntun ke suatu taksiran menyeluruh tentang kebaikan setiap alternatif; (8) tawar menawar, AHP mempertimbangkan prioritas-prioritas relatif dari berbagai faktor sistem dan memungkinkan organisasi memilih alternatif terbaik berdasarkan tujuan-tujuan mereka; (9) penilaian dan konsesus, AHP tidak memaksakan konsesus tetapi mensintesiskan suatu hasil yang representatif dari berbagai penilaian yang berbeda; (10) pengulangan proses, AHP memungkinkan organisasi memperhalus definisi mereka pada suatu persoalan dan memperbaiki pertimbangan dan pengertian mereka melalui pengulangan. 


\section{Prototyping}

Prototipe memberikan ide bagi pembuat maupun pemakai potensial tentang cara sistem akan berfungsi dalam bentuk lengkapnya. Proses menghasilkan sebuah prototipe disebut dengan prototyping (McLeod, 2001).

\section{Daya Tarik Prototyping}

Baik pemakai maupun spesialis informasi menyukai prototyping, untuk alasan-alasan seperti: komunikasi antara analisis sistem dan pemakai membaik; analis dapat bekerja lebih baik dalam menentukan kebutuhan pemakai; pemakai berperan lebih aktif dalam pengembangan sistem; spesialis informasi dan pemakai menghabiskan lebih sedikit waktu dan usaha dalam mengembangkan sistem; penerapan menjadi lebih mudah karena pemakai mengetahui apa yang diharapkannya.

\section{Pengertian Gagal Jantung}

Gagal jantung kongestif adalah sindrom klinik yang ditimbulkan oleh gangguan fungsi jantung yang dapat berupa menurunnya kontraktilitas, berkurangnya massa jantung yang berkontraksi, gangguan sinergi kontraksi, atau berkurangnya kelenturan. Sindrom ini terjadi karena curah jantung tidak memadai untuk memenuhi kebutuhan metabolisme tubuh. Gangguan fungsi pompa jantung itu menyebabkan bendungn sirkulasi dengan segala akibatnya. Tujuan utama pengobatan gagal jantung adalah mengurangi gejala akibat bendungan sirkulasi, memperbaiki kapasitas kerja dan kualitas hidup, serta memperpanjang harapan hidup. Untuk itu pendekatan awal adalah memperbaiki berbagai gangguan yang mampu pulih untuk menghilangkan beban kardiovaskular yang berlebihan, misalnya mengobati hipertensi, mengobati anemia, mengurangi berat badan, atau memperbaiki stenosis aorta. Gagal jantung yang tetap bergejala walaupun penyakit yang mendasarinya telah diobati memerlukan pembatasan aktivitas fisik, pembatasan asupan garam, dan obat (Bagian Farmakologi Fakultas Kedokteran Universitas Indonesia, 2005)

Kebanyakan penderita gagal jantung memperlihatkan gangguan fungsi sistolik. Pada penderita demikian terapi obat dimaksud untuk menghilangkan gejala bendungan sirkulasi dengan memperbaiki kontraktilitas miokard, dan mengurangi beban pengisian ventrikel (preload - beban hulu), dan menurunkan tahanan perifer (afterload - beban hilir). Obat-obat utama untuk tujuan itu adalah glikosida digitalis dan zat inotropik lainnya untuk memperbaiki kontraktilitas, diuretik untuk mengurangi beban hulu dan pada akhirnya juga beban hilir, serta vasodilator yang mengurangi beban hilir.

Digitalis semula merupakan obat yang selalu diberikan kepada penderita gagal jantung. Tetapi ternyata bahwa efektivitas diuretik pada gagal jantung sama dengan digitalis, terutama pada pasien dengan edema sebagai gejala utama gagal jantung. Efek utama glikosida jantung adalah terhadap fungsi mekanik dan listrik jantung. Manfaatnya pada gagal jantung kongestif terutama karena efek peningkatan kontraktilitas jantung. Namun manfaat jangka lama pada penderita ini masih diragukan. Glikosida jantung yang sekarang banyak digunakan mempunyai batas keamanan yang sempit, sehingga terasa perlu menemukan obat lain yang kurang toksin tetapi dengan khasiat inotropik yang sama. Beberapa obat baru misalnya amrinon dan beberapa perangsang adrenoseptor- $\beta$ kini terbukti bermanfaat untuk mengatasi gagal jantung. Beberapa vasodilator yaitu nitroprusid, nitrogliserin, $\alpha$ bloker dan penghambat enzim konversi angiotensin, telah terbukti berguna pada gagal jantung tertentu. Penelitian mutakhir telah membuktikan bahwa penghambat ACE dan vasodilator lain sangat bermanfaat dalam menurunkan angka kematian gagal jantung. 


\section{Sejarah Digitalis}

Tanaman obat yang mengandung glikosida jantung sudah dikenal sejak zaman mesir kuno. Bangsa romawi menggunakannya sebagai diuretik, penguat jantung, perangsang muntah, dan racun tikus. Dalam dunia kedokteran modern, kegunaan digitalis sebagai obat telah dikukuhkan oleh William Withering (1875) dalam risalahnya yang berjudul An Account of the Foxglove and Some of Its Medical Uses: Eith Practical Remarks on Dropsy and Other Diseases. Dalam tulisan tersebut, dikemukakan bahwa digitalis mempunyai kekuatan terhadap jantung yang melebihi obat lainnya, dan kekuatan ini dapat diarahkan ke tujuan-tujuan yang bermanfaat. Disamping itu, digitalis harus digunakan secara cermat berhubung efek toksinnya mudah timbul.

\section{Efek Langsung Digitalis}

Mekanisme meningkatnya kontraktilitas otot jantung oleh digitalis sangat kompleks. Besarnya efek ini sesuai dengan besarnya dosis. Efek ini berlaku untuk otot atrium dan ventrikel, dan secara kualitatif sama untuk otot jantung yang normal maupun yang gagal. Efek terhadap aktivitas mekanik ini terlihat pada kontraksi isometrik maupun isotonik. Digitalis yang diberikan pada sediaan otot jantung dalam kondisi isometrik akan meningkatkan tegangan otot. Disamping itu, digitalis meningkatkan kecepatan timbulnya tegangan ini dan memperpendek waktu yang diperlukan untuk mencapai puncak tegangan. Efek ini terjadi tanpa adanya perubahan dalam tegangan istirahat. Secara kualitatif, keadaan ini dapat disamakan dengan keadaan ketika jantung teregang pada akhir diastole.

\section{Penyebab Penyakit Jantung}

Penyakit jantung dapat disebabkan oleh merokok, kolesterol tinggi, tekanan darah tinggi, tidak olahraga (exercise) dan kelebihan berat badan (overweight).

\section{Faktor Resiko untuk Penyakit jantung Coroner}

Menurut Widjaja (2008), ada 2 faktor yaitu (1) faktor yang tidak bisa dikendalikan seperti keturunan, umur, dan jenis kelamin (pria mempunyai resiko lebih tinggi dari pada wanita); (2) faktor yang bisa dikendalikan seperti merokok, tekanan darah tinggi, kadar lemak yang tinggi dalam darah, kurang olah raga, diabetes yang tidak terkendali, stres dan kegemukan.

\section{PEMBAHASAN}

\section{Tahapan Perancangan}

\section{Perancangan State Transition Diagram}

Untuk perancangan State Transition Diagram pada layar menu utama akan ditunjukkan pada Gambar 1 berikut ini. 


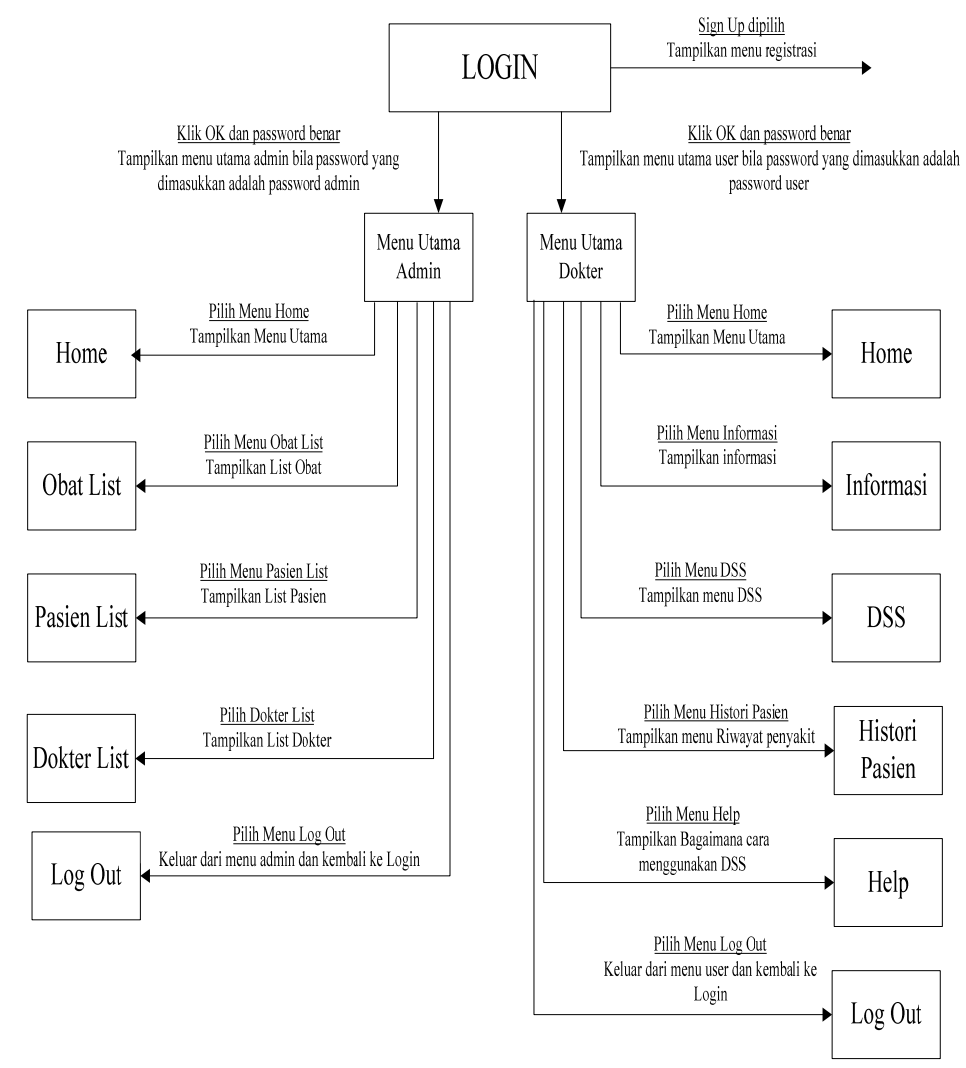

Gambar 1 Rancangan STD untuk Layar Menu Utama

\section{Perancangan Basis Data} berikut.

Untuk tahapan perancangan basis data digunakan hubungan antar tabel seperti pada Gambar 2

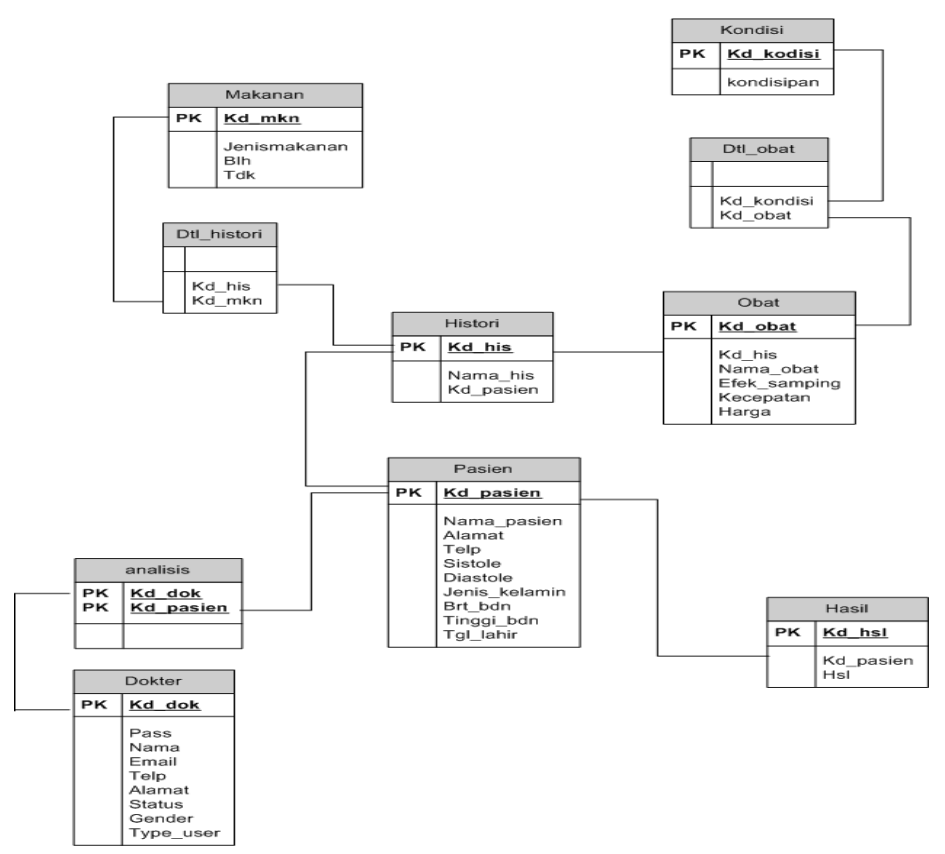

Gambar 2 Hubungan Antar Tabel 


\section{Perancangan Basis Model}

berikut.

Perancangan basis modelnya menggunakan model perhitungan AHP seperti pada Gambar 3

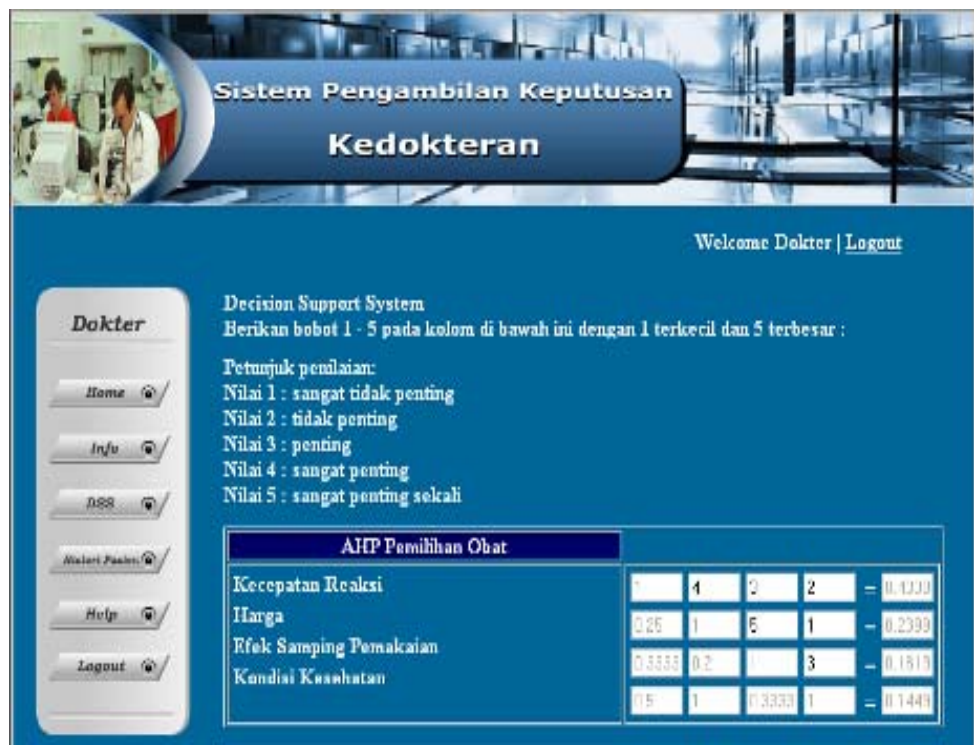

Gambar 3 Perhitungan AHP

\section{Perancangan User Interface}

Gambar 4 dan Gambar 5 adalah tampilan untuk halaman login dan halaman home dari perancangan sistem penunjang keputusan untuk penanganan penderita jantung.

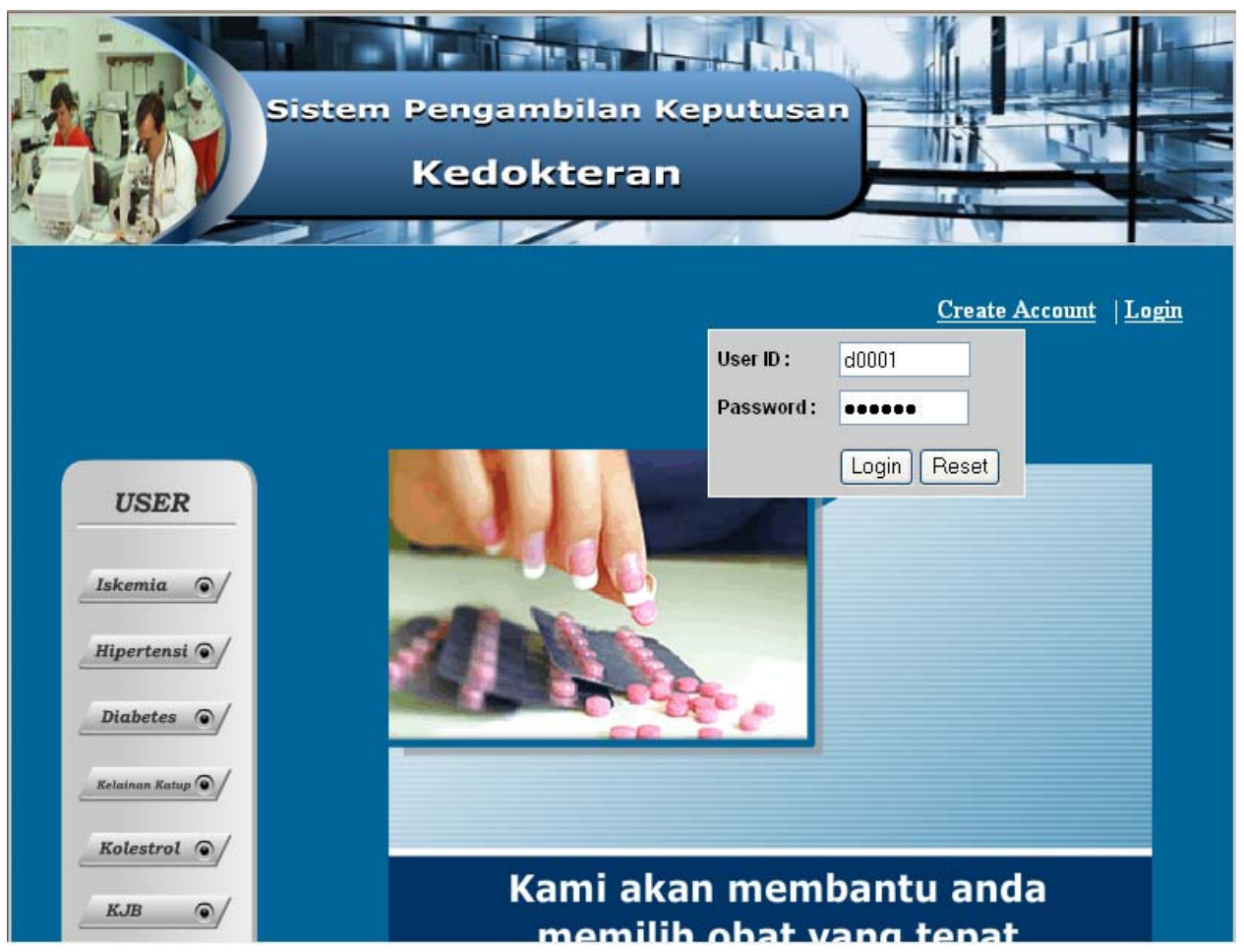

Gambar 4 Form Login 


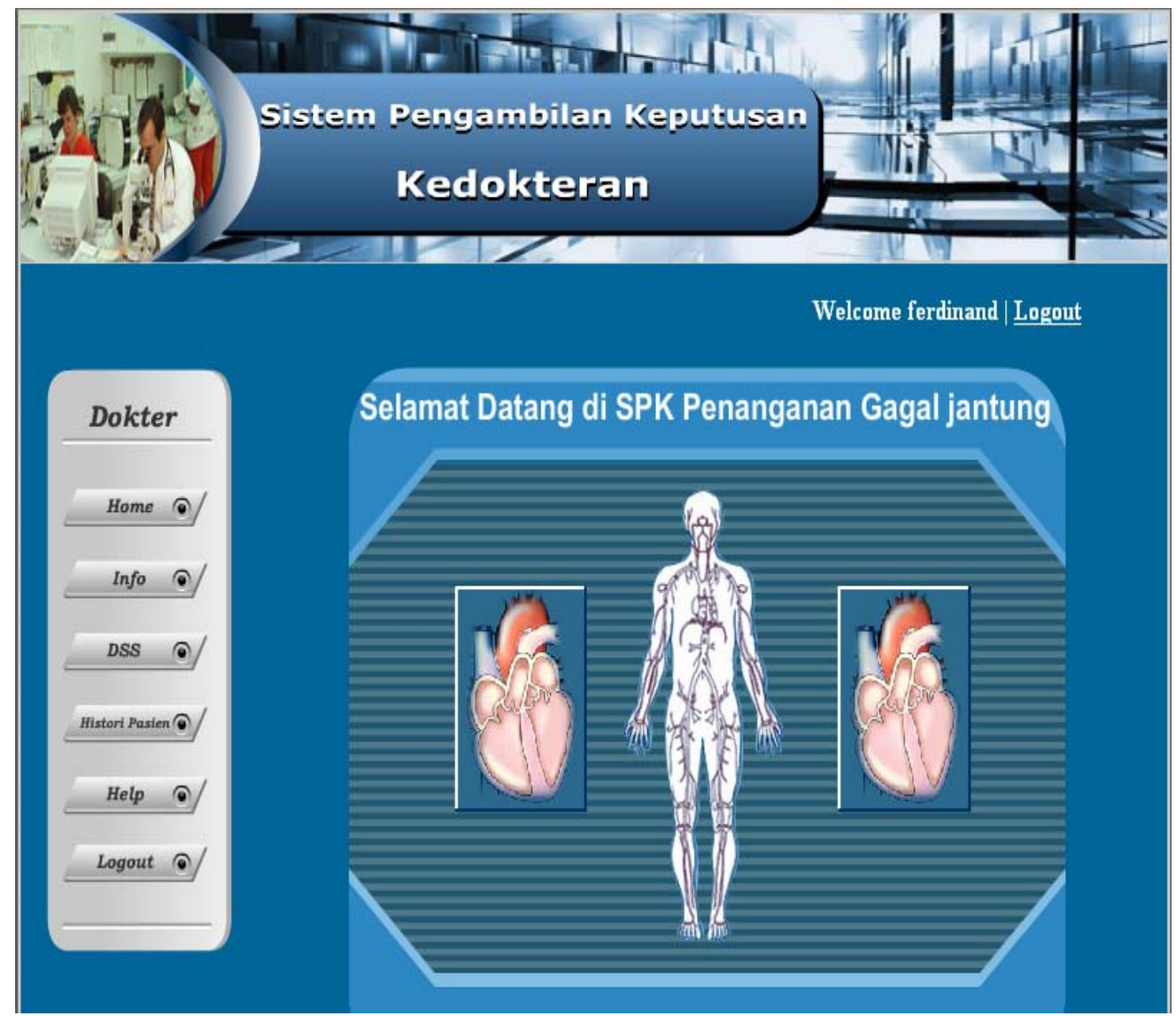

Gambar 5 Form Home

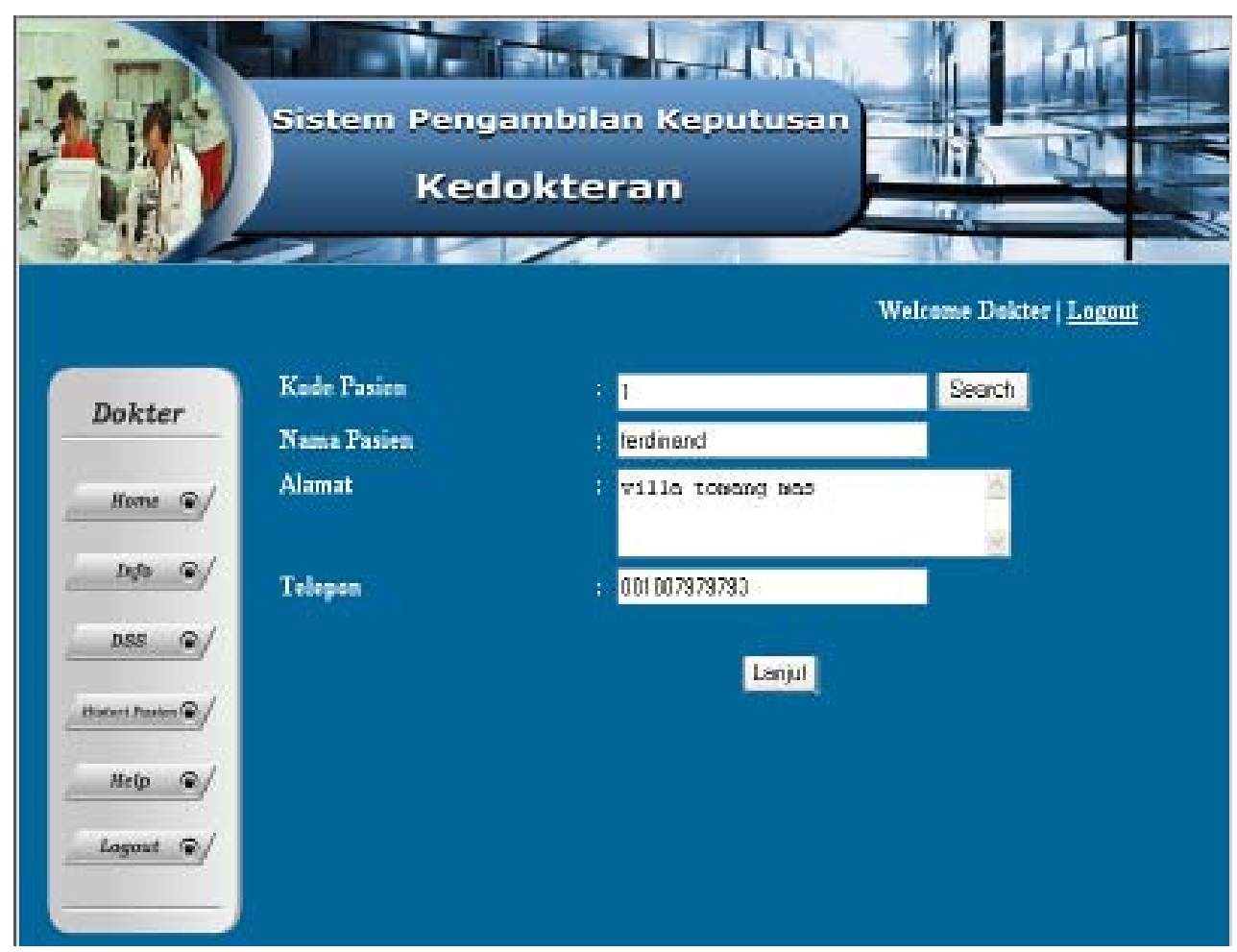

Gambar 6 Form DSS 1 


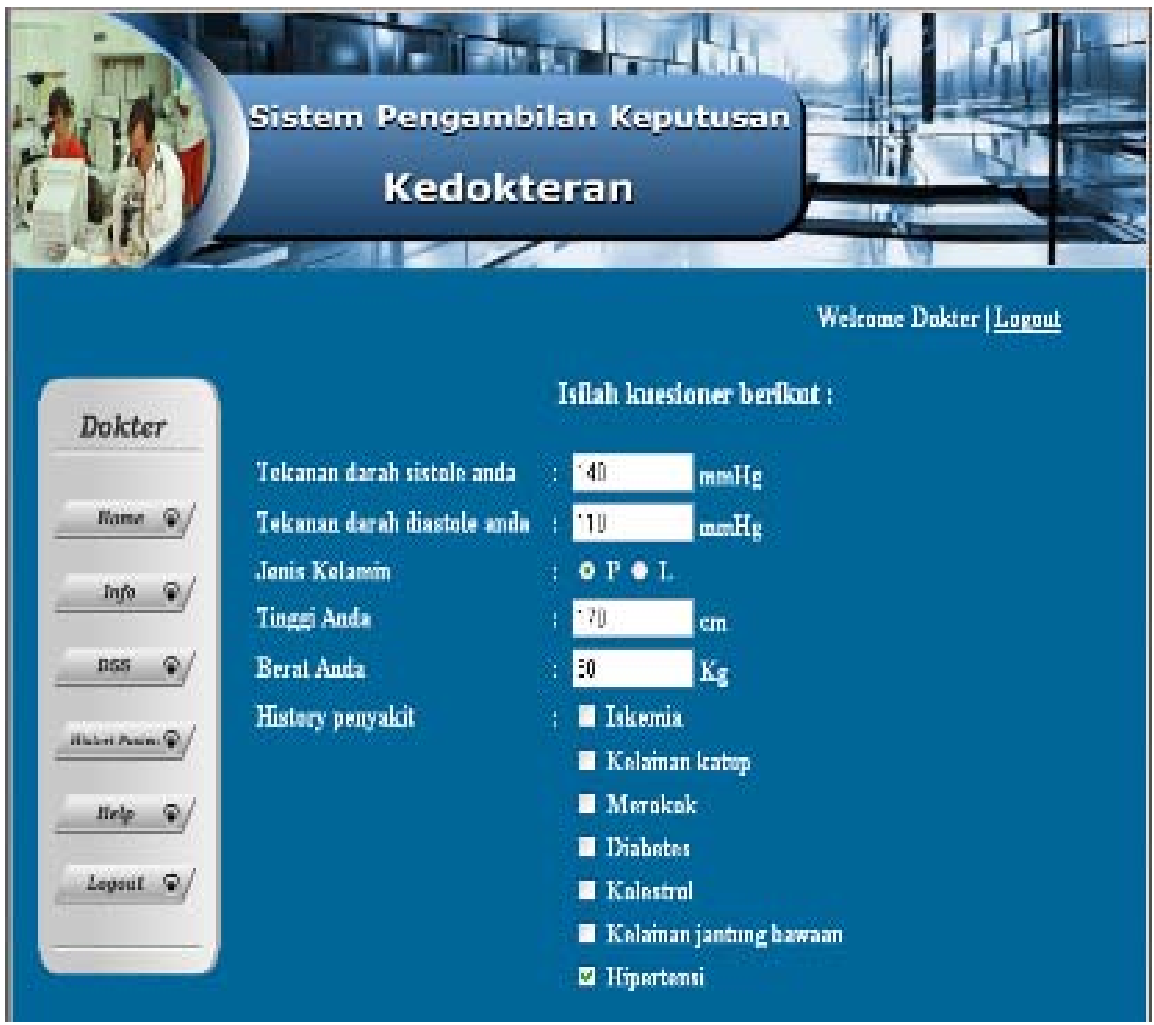

Gambar 7 Form DSS 2

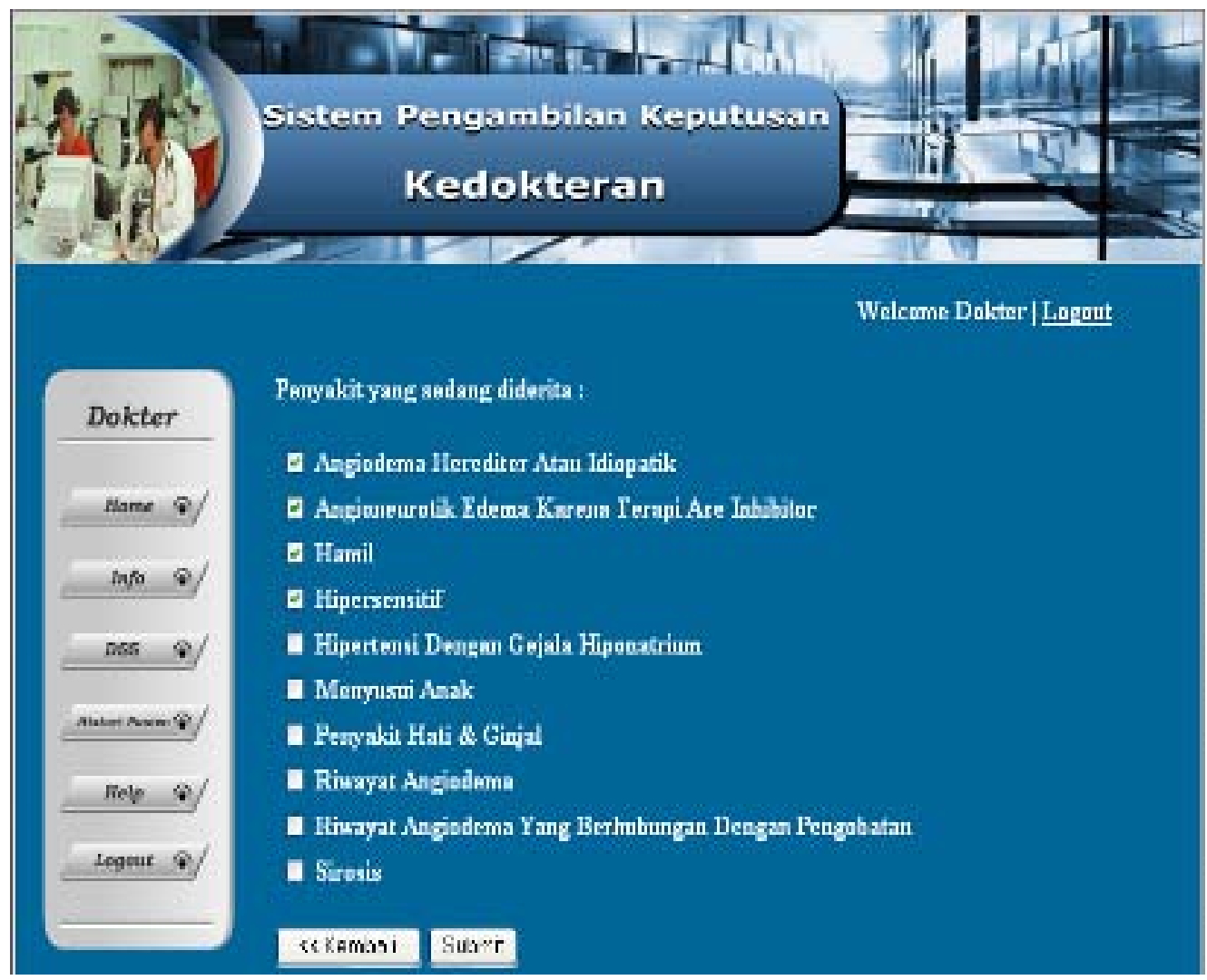

Gambar 8 Form DSS 3 


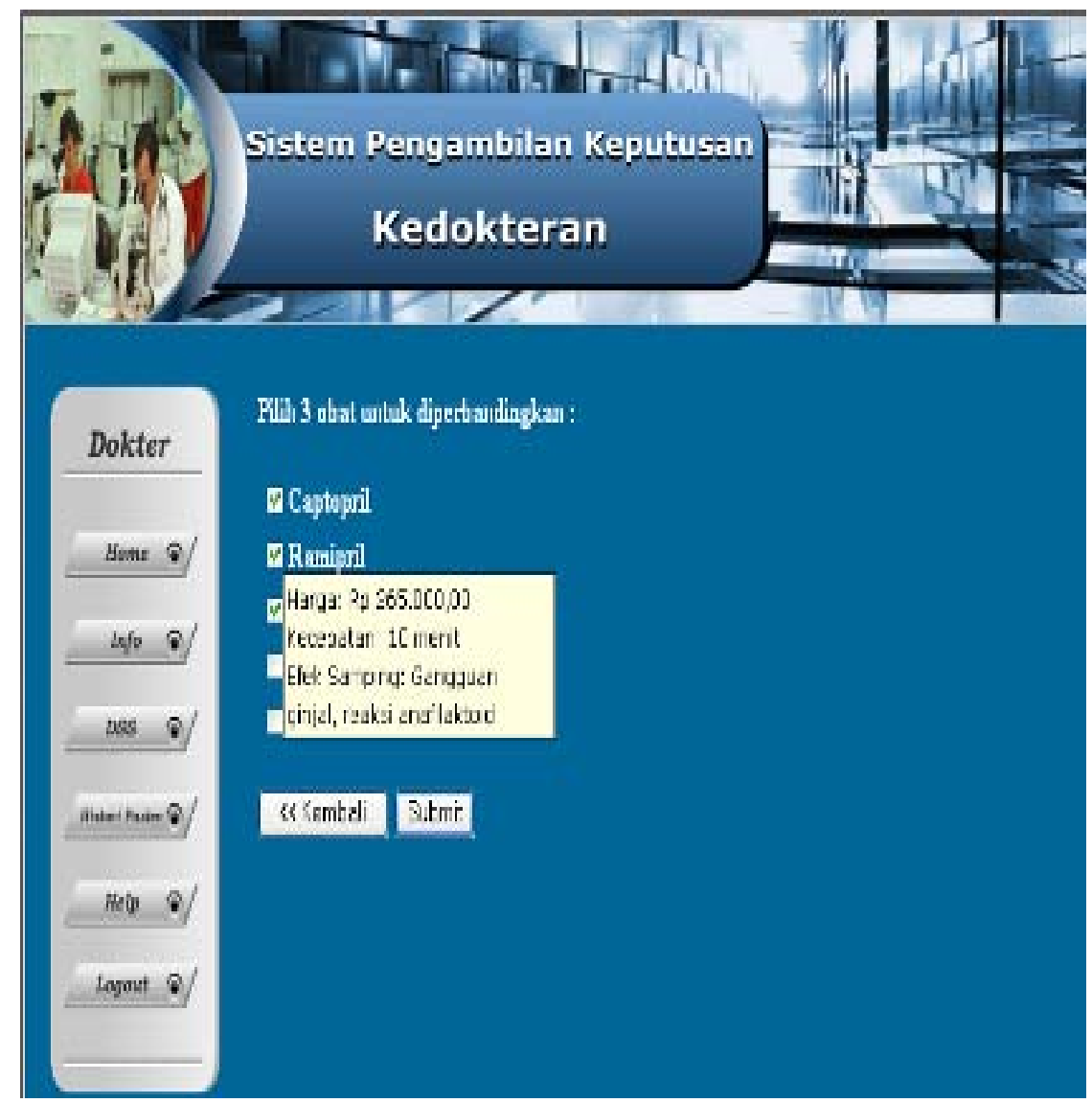

Gambar 9 Form DSS 4

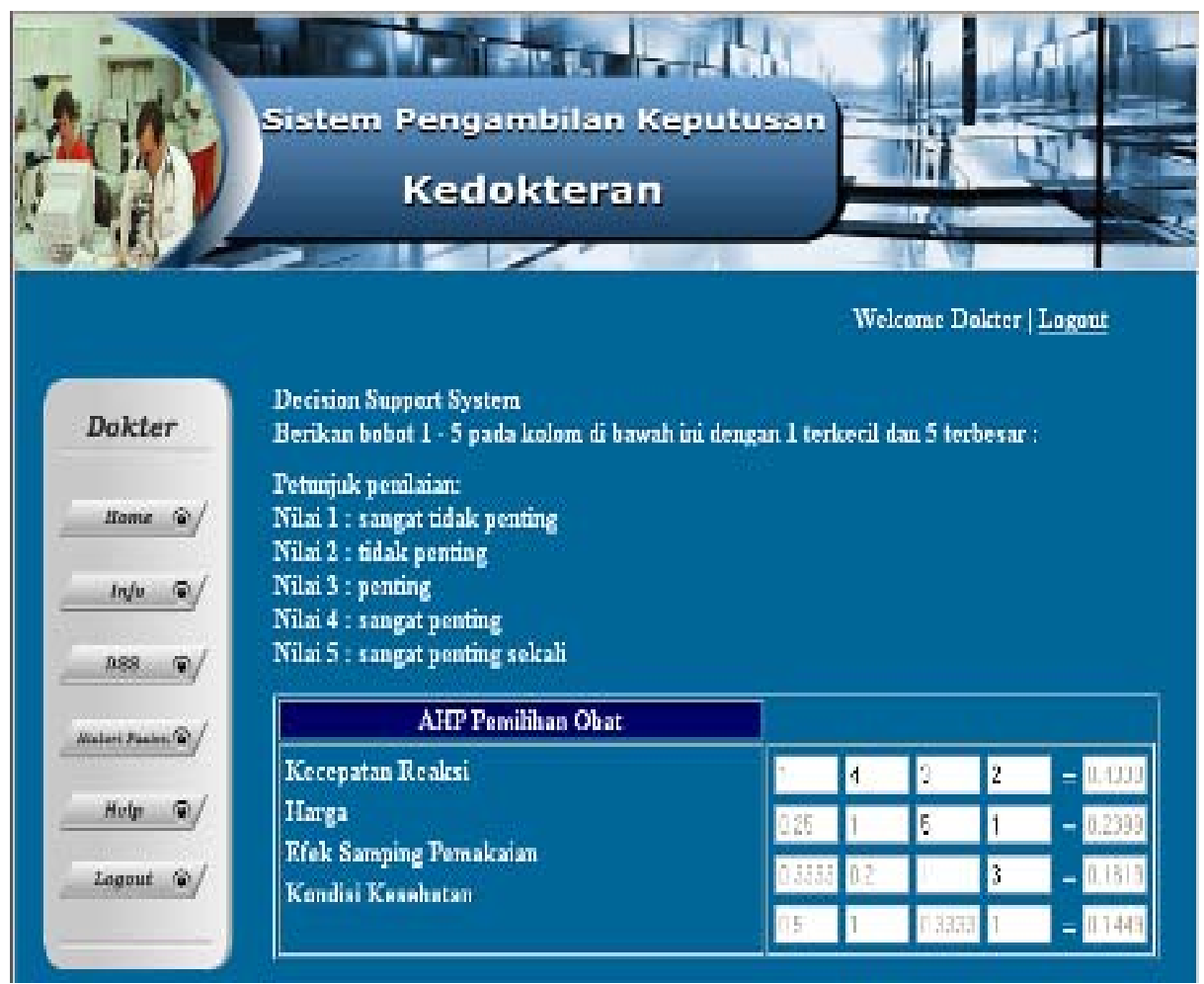

Gambar 10 Form DSS 5 


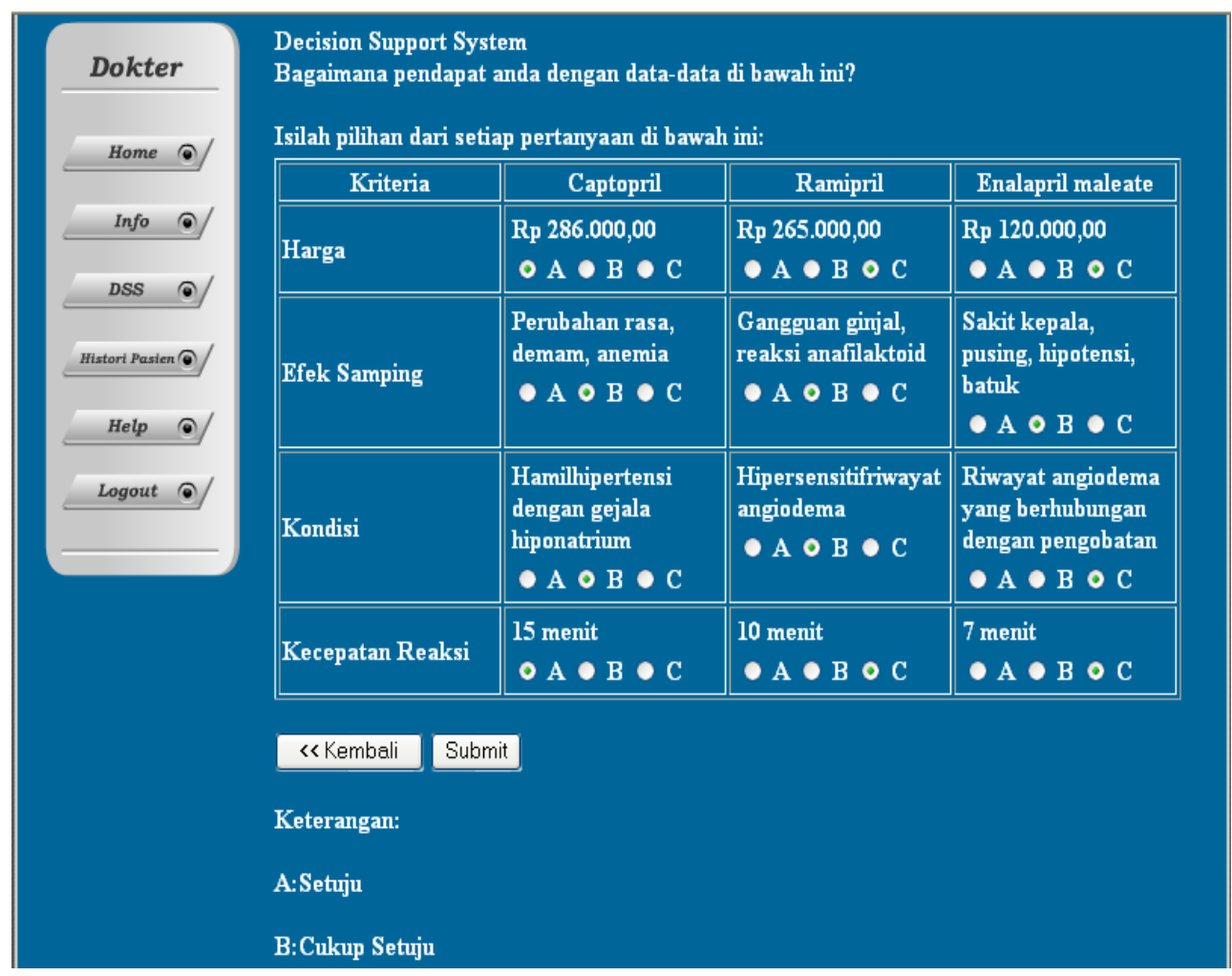

Gambar 11 Form DSS 6

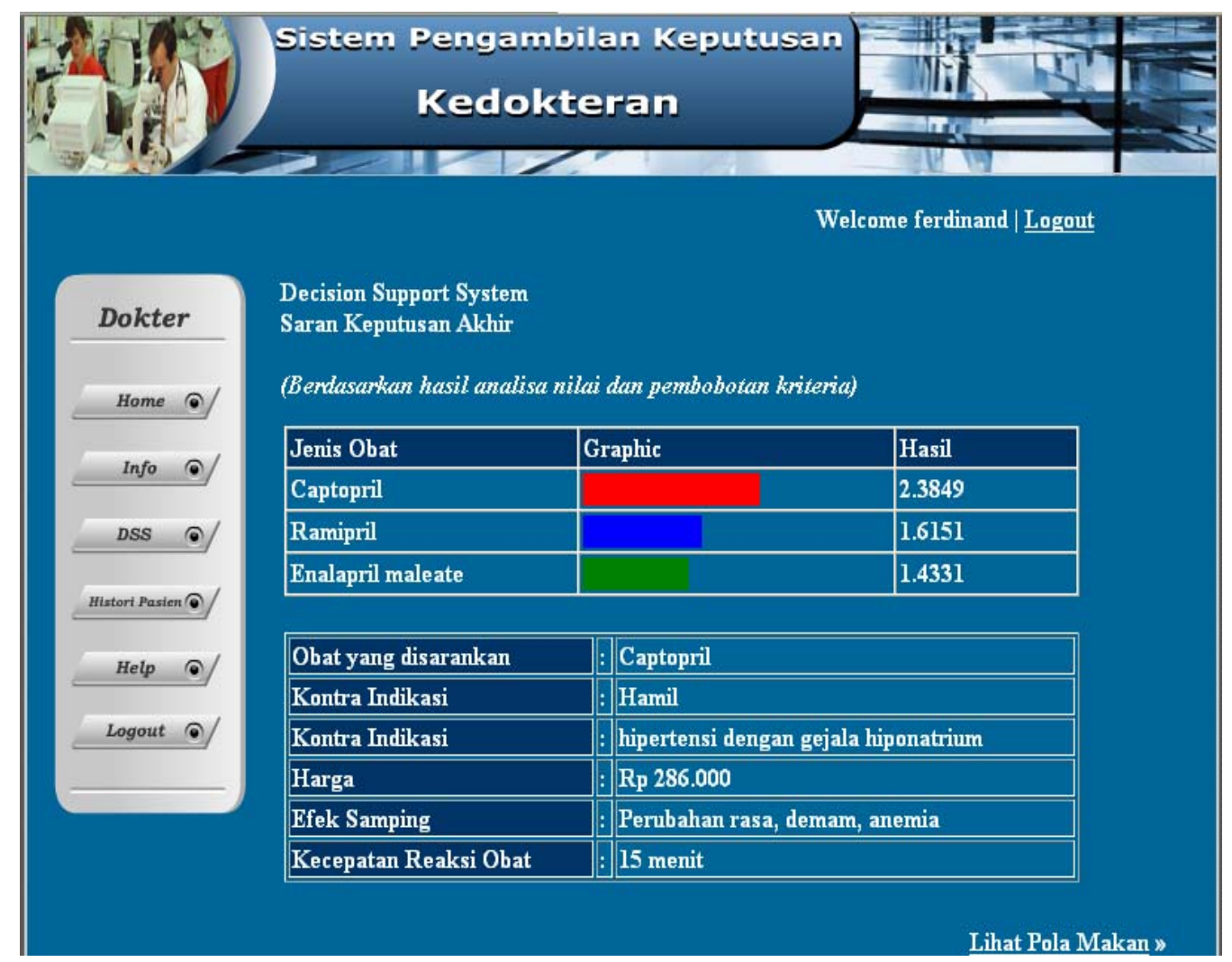

Gambar 12 Form DSS 7 


\section{SIMPULAN}

Dari tulisan ini, dapat disimpulkan bahwa (1) sistem penunjang keputusan ini dapat membantu dokter dalam memutuskan jenis obat yang sesuai bagi penderita gagal jantung; (2) sistem penunjang keputusan ini memberikan informasi tentang gambaran umum seputar penyakit gagal jantung.

Dari simpulan dan pembahasan di atas, dapat disarankan hal-hal bahwa sistem penunjang keputusan ini dapat dikembangkan untuk penanganan penderita penyakit lainnya. Diperlukan adanya pemeliharaan (maintenance) dan pembaruan data (update) secara berkala, agar informasi yang tersedia tetap terjaga dan akurat.

\section{DAFTAR PUSTAKA}

Turban, E., Aronson, J. E., \& Liang, T. P. (2005). Decision Support System \& Inteligent Systems (7th ed.). (D. Prabantini, Terj.). Yogyakarta: ANDI.

McLeod, Jr., R. (2001). Management Information Systems: A Study of Computer Based Information Systems. New York: Macmillan Publishing Company.

Marimin. (2004). Teknik dan Aplikasi Pengambilan Keputusan Kriteria Majemuk. Jakarta: Grasindo.

Bagian Farmakologi Fakultas Kedokteran Universitas Indonesia. (2005). Farmakologi dan Terapi (4th ed.). Jakarta: Gaya Baru.

Widjaja, U. (2008). Penyakit Jantung Bagaimana Anda Mengurangi Resikonya, dari http://www.geocities.com/alam_penyakit/PenyakitJantungKoronari.html , 22 februari 2008. 